\title{
Novel Adipose Tissue Targets to Prevent and Treat Atherosclerosis
}

\section{Ludger Scheja and Joerg Heeren}

\section{Contents}

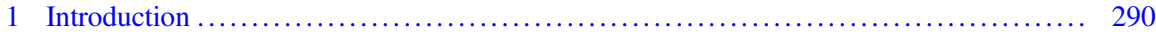

2 Types of Adipose Tissue and Their Impact on Cardiovascular Disease ............... 292

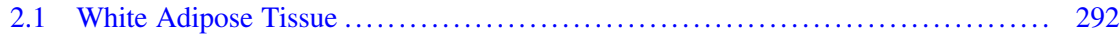

2.2 Thermogenic Adipose Tissue .......................................... 294

2.3 Perivascular Adipose Tissue ........................................ 295

3 Therapies Targeting Adipose Tissue with Proven Clinical Efficacy in the Treatment of Atherosclerosis ....................................................... 296

3.1 Peroxisome Proliferator-Activated Receptor- $\gamma($ PPAR $\gamma)$ Agonists .............. 296

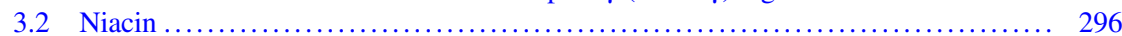

3.3 Renin-Angiotensin System Blockade ................................... 297

4 Novel Therapeutic Targets in Adipose Tissue for Treatment of Atherosclerosis ......... 297

4.1 Promoting Lipoprotein Disposal and Lipid Storage in Adipose Tissues ........... 297

4.2 Boosting Thermogenic Activation ..................................... 299

4.3 Targeting Inflammation in Adipose Tissue .............................. 299

4.4 Hormones Derived from Thermogenic Adipose Tissue ..................... 300

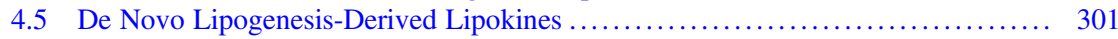

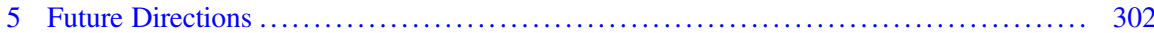

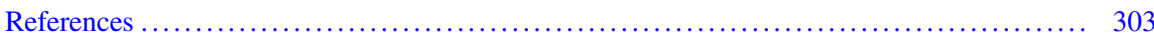

\section{Abstract}

Adipose tissue as a major organ of lipid and lipoprotein metabolism has a major impact on metabolic homeostasis and thus influences the development of atherosclerosis and related cardiometabolic diseases. Unhealthy adipose tissue, which is often associated with obesity and systemic insulin resistance, promotes the development of diabetic dyslipidemia and can negatively affect vascular tissue

\footnotetext{
L. Scheja $(\bowtie) \cdot$ J. Heeren

Department of Biochemistry and Molecular Cell Biology, University Medical Center HamburgEppendorf, Hamburg, Germany

e-mail:1.scheja@uke.de
} 
homeostasis by secreting pro-inflammatory peptides and lipids. Conversely, paracrine and endocrine factors that are released from healthy adipose tissue can preserve metabolic balance and a functional vasculature. In this chapter, we describe adipose tissue types relevant for atherosclerosis and address the question how lipid metabolism as well as regulatory molecules produced in these fat depots can be targeted to counteract atherogenic processes in the vessel wall and improve plasma lipids. We discuss the role of adipose tissues in the action of approved drugs with anti-atherogenic activity. In addition, we present potential novel targets and therapeutic approaches aimed at increasing lipoprotein disposal in adipose tissue, boosting the activity of heat-producing (thermogenic) adipocytes, reducing adipose tissue inflammation, and improving or replacing beneficial hormones released from adipose tissues. Furthermore, we describe the future potential of innovative drug delivery technologies.

\section{Keywords}

Adipokines - Atherosclerosis - Brown adipose tissue - Diabetic dyslipidemia · Hyperlipidemia · Inflammation · Insulin resistance · Lipid-lowering therapy · Lipoproteins · Obesity · Perivascular adipose tissue $\cdot$ Thermogenesis $\cdot$ Vascular remodeling $\cdot$ White adipose tissue

\section{Introduction}

Adipocytes are triglyceride-storing cells present in anatomically distinct adipose tissue depots throughout the mammalian body (Cinti 2001). Originally, two major subtypes, white and brown adipocytes, were identified, both playing an important role in energy metabolism. White adipocytes in white adipose tissue (WAT) store large amounts of triglycerides, typically in a single large lipid droplet, which can be hydrolyzed to provide other organs with free fatty acids (FFA) (Young and Zechner 2013). Brown adipocytes in brown adipose tissue (BAT) also store triglycerides, albeit in lower quantities, and, in many, smaller lipid droplets. When BAT is activated, for example, by exposure to a cold environment, brown adipocytes oxidize fatty acids, glucose, and other fuels in their numerous mitochondria to generate heat (Cannon and Nedergaard 2004). Under chronic cold exposure, adipocytes that are morphologically and functionally very similar to brown adipocytes, referred to as beige adipocytes, develop in WAT depots in a process called WAT browning (Bartelt and Heeren 2014). The number of thermogenic adipocytes thus increases when demand is high. As summarized in Fig. 1, white, brown, and beige adipocytes influence whole-body energy metabolism, lipoprotein levels (Scheja and Heeren 2016), and, through secretion of regulatory molecules, tissue homeostasis in other organs (Scheja and Heeren 2019). How these systemic effects of adipose tissues modulate the development of cardiovascular disease (CVD), and how they can be targeted therapeutically, is the topic of this chapter. Furthermore, local effects exerted by adipocytes found next to blood vessels (perivascular adipocytes) will be described and discussed. 


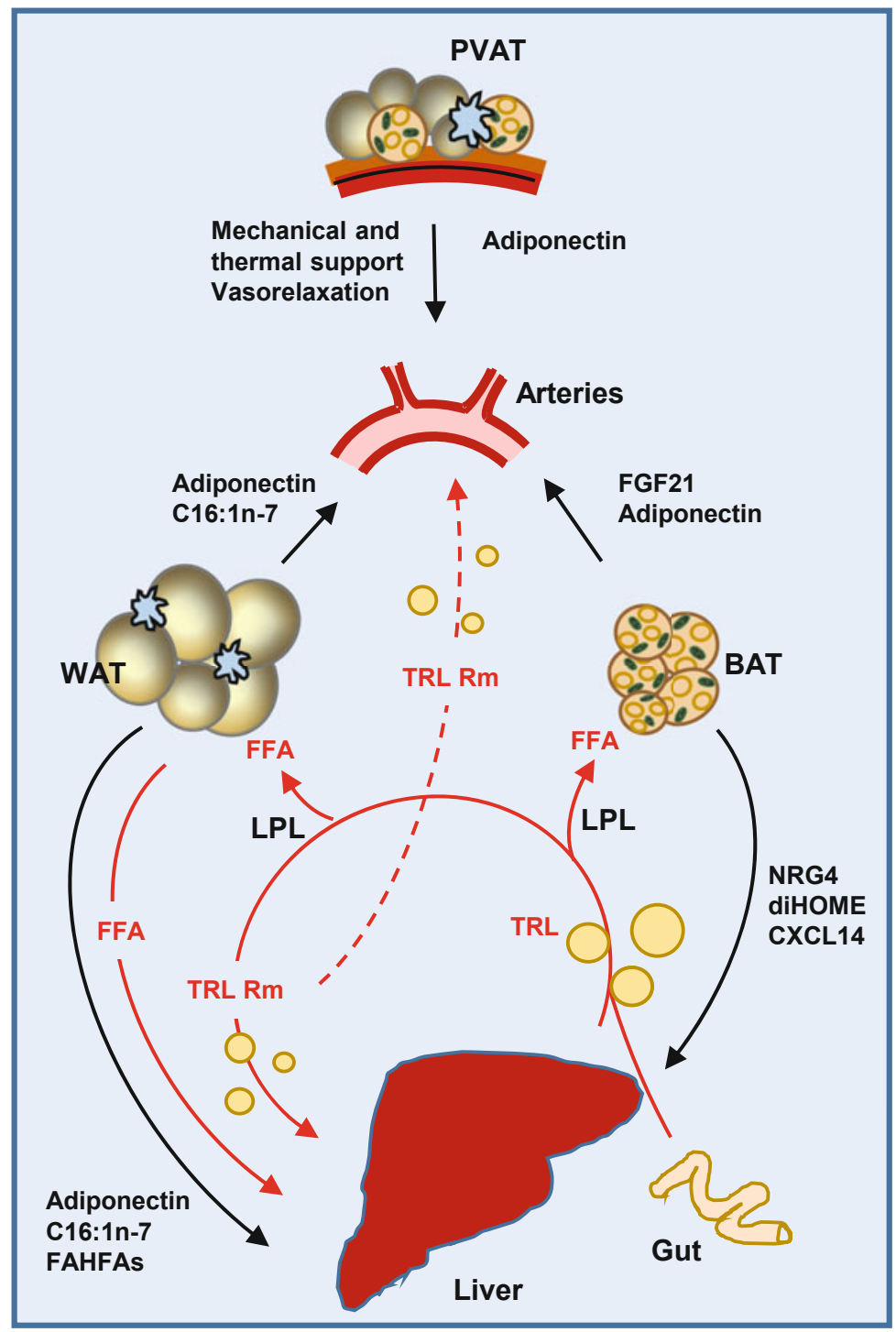

Fig. 1 Role of adipose tissues for cardiometabolic homeostasis under healthy conditions. In metabolic health, white and brown adipose can control systemic lipid homeostasis by regulating both the efficient clearance of triglyceride-rich lipoproteins and the release of fatty acids under catabolic conditions. Healthy adipose tissues harbor mostly anti-inflammatory immune cells (indicated by blue-colored immune cells) that are important to maintain tissue homeostasis. Under this condition, adipocytes mostly release beneficial hormones such as anti-inflammatory lipokines, adiponectin, and FGF21 that support vascular health by direct effects on arteries or indirectly by regulating hepatic lipid metabolism. Overall, healthy adipose tissues are associated with a state of metabolic flexibility that prevents atherosclerosis. BAT brown adipose tissue, $F F A$ free fatty acids, $F G F 21$ fibroblast growth factor 21, $L P L$ lipoprotein lipase, $N R G 4$ neuregulin 4, PVAT perivascular adipose tissue, $R m$ remnants, $T R L$ triglyceride-rich lipoproteins, WAT white adipose tissue 


\section{Types of Adipose Tissue and Their Impact on Cardiovascular Disease}

\subsection{White Adipose Tissue}

The bulk of triglycerides in the body is stored in subcutaneous and intra-abdominal WAT depots. The stored fatty acids can be released from white adipocytes by intracellular triglyceride lipolysis (Young and Zechner 2013). Norepinephrine, which is secreted by sympathetic nerves and signals through $\beta$-adrenergic receptors, is the major physiological trigger of lipolysis. $\beta$-Adrenergic stimulation elevates cyclic AMP, thereby activating adipose tissue triglyceride lipase (ATGL) and hormone-sensitive lipase (HSL). This regulation ensures that in catabolic states such as fasting or endurance exercise, WAT releases FFA into the circulation to provide other organs with energy. In contrast, after feeding, intracellular lipolysis is suppressed by insulin, and WAT takes up dietary fatty acids from circulating triglyceride-rich lipoproteins (TRL). In this anabolic process, TRL triglycerides are hydrolyzed by lipoprotein lipase (LPL) bound to the luminal side of the capillary endothelium, and the FFA then pass through the endothelium to be taken up and esterified by the adipocytes (Kersten 2014). Apart from their role in fatty acid metabolism, white adipocytes are also an important source of adipokines (adipose peptide hormones) and other secreted regulatory molecules. Notably, only a few of them such as leptin and adiponectin are exclusively expressed in adipose tissue and act at the same time as a true endocrine hormone. In other words, most adipokines are also expressed by cells other than adipocytes and may act predominantly in a paracrine fashion (Scheja and Heeren 2019).

In prolonged periods of caloric surplus, i.e., when energy uptake exceeds energy expenditure, WAT depots expand by increasing adipocyte number (hyperplasia) and adipocyte size (hypertrophy). The resulting overweight or obesity is detrimental when adipocyte hypertrophy prevails (Klöting et al. 2010). In this state of unhealthy obesity, chronic low-grade inflammation occurs in WAT (Crewe et al. 2017), adipocytes become insulin resistant, and fatty acids cannot be stored efficiently any longer. Hence, they are ectopically deposited as part of various lipid species in other organs, a process believed to contribute to the systemic insulin resistance typically associated with obesity (Petersen and Shulman 2018). Another important consequence of limited WAT lipid storage in obesity is liver steatosis. Among other effects, this causes increased secretion of very low-density lipoproteins (VLDL) and thus promotes diabetic dyslipidemia (Scheja and Heeren 2016). Together with pro-inflammatory changes in adipokine patterns, dyslipidemia links expanded WAT depots, especially abdominal visceral fat (Lim and Meigs 2014), to the increased atherosclerosis risk observed in obese individuals (Fig. 2). 


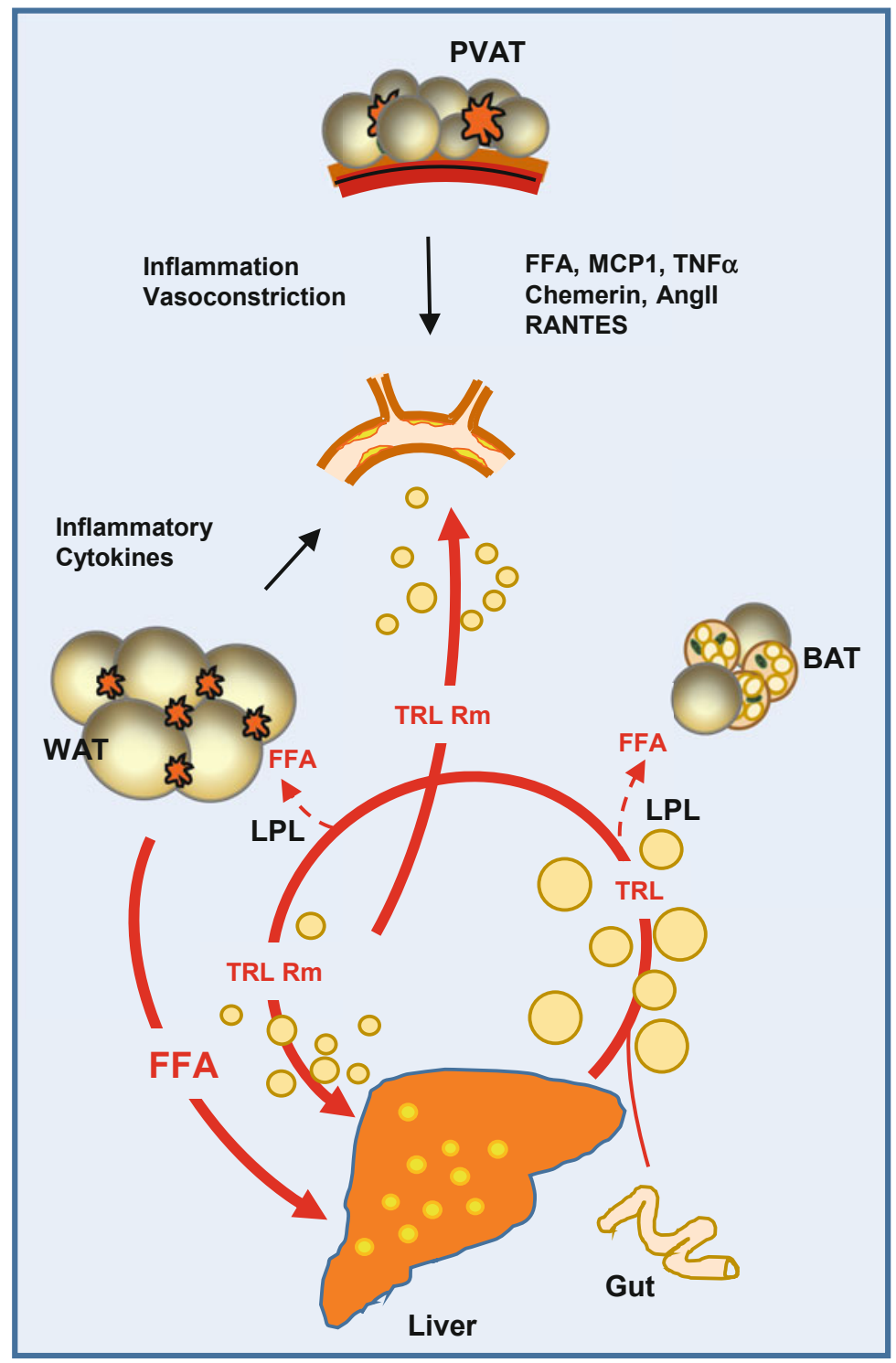

Fig. 2 Hypertrophy and inflammation in adipose tissues cause dyslipidemia and promote atherosclerosis. Chronic caloric surplus and low energy expenditure result in obesity, which is characterized by inflamed (indicated by red-colored immune cells) and hypertrophic adipose tissues as well as dysfunctional brown adipose tissues. Eventually, this causes atherogenic dyslipidemia due to impaired TRL clearance and enhanced fatty acid flux to the liver leading to increased lipoprotein secretion. The lower release of adipocyte-derived anti-inflammatory molecules (see Fig. 1) and pro-inflammatory cytokines in particular those released by PVAT promote inflammation and vasoconstriction. Overall, this creates an immunometabolic state that promotes atherosclerotic plaque formation 


\subsection{Thermogenic Adipose Tissue}

Brown adipocytes present in distinct BAT depots (Zhang et al. 2018) generate heat to maintain body temperature by non-shivering thermogenesis (NST), a process that depends on the mitochondrial proton transporter uncoupling protein-1 (UCP1) that disconnects the respiratory chain from ATP synthesis (Cannon and Nedergaard 2004). NST is triggered by activation of lipolysis through increased $\beta$-adrenergic signaling and other catabolic stimuli (Bordicchia et al. 2012). Fatty acids released from the lipid droplets allosterically activate UCP1 and serve as mitochondrial fuel. During prolonged thermogenic stimulation by cold exposure, or other sustained catabolic stimuli such as burn trauma (Sidossis et al. 2015), mitochondria-rich beige adipocytes appear in WAT, a phenomenon called WAT browning (Bartelt and Heeren 2014). Although these adipocytes appear to be developmentally distinct, they are very similar to brown adipocytes with regard to gene expression, morphology, and function. Both brown and beige adipocytes exhibit a very high metabolic capacity and can combust large quantities of triglycerides and other sources of energy when activated. In cold-treated mice, BAT internalizes high amounts of triglycerides from circulating TRL (Bartelt et al. 2011). Under this condition, cholesterol-enriched TRL remnants are efficiently cleared by the liver where bile acid synthesis from cholesterol is increased (Worthmann et al. 2017). Furthermore, the flux of high-density lipoprotein (HDL) cholesterol from the periphery to the liver is enhanced (Bartelt et al. 2017). Consistent with the observed improved lipoprotein profiles, the size of atherosclerotic plaques was reduced in BAT-activated mice fed a cholesterol-rich diet compared to controls (Chang et al. 2012, Berbée et al. 2015). Of note, this beneficial outcome on atherosclerosis depends on lowering of plasma remnant cholesterol, as it was not observed in experiments with mouse models of severely compromised hepatic remnant clearance (LDL receptor (LDLR)- or apolipoprotein (apo) E-deficient mice) where BAT activation and thus TRL processing resulted in elevation of plasma remnant cholesterol (Berbée et al. 2015; Sui et al. 2019). Whether activated BAT or beige WAT has enough metabolic capacity to reduce atherosclerosis in humans needs to be shown. However, a recent, large epidemiological study indicates that high BAT mass inversely correlates with the risk of type 2 diabetes and major cardiometabolic diseases (Becher et al. 2020). Relative to body weight, BAT mass is smaller in humans than in rodents, and it apparently declines in obesity (van Marken Lichtenbelt et al. 2009). However, humans usually live under thermoneutrality, defined as an environmental temperature where the basal metabolic rate generates sufficient heat to maintain body core temperature. When mice are kept under thermoneutral conditions (ca. $30{ }^{\circ} \mathrm{C}$; in dressed humans approximately $24{ }^{\circ} \mathrm{C}$ ), BAT accumulates lipid and partially loses mitochondria, UCP1, and other determinants of thermogenic capacity (Kotzbeck et al. 2018). Thus, it is likely that in humans, reactivation of BAT and induction of beige WAT, for example, by repeated cold treatments, would profoundly increase metabolic rate and hence the capacity to metabolize atherogenic lipoproteins. Another issue is that metabolic imaging studies to quantify BAT activity in humans are usually done with radioactive glucose analogues. Suitable tracer analogues of 
TRL, the major physiological fuel of BAT, still need to be developed. Most adipokines are expressed by both WAT and BAT, and due to its smaller size, BAT is probably less important. However, several adipokines are enriched in thermogenic adipose tissue, and some are induced and released from BAT under thermogenic stimulation or stress conditions (Villarroya et al. 2017). Overall, dysfunctional BAT is likely to influence atherosclerotic development especially by promoting dyslipidemia and inflammation (Fig. 2).

\subsection{Perivascular Adipose Tissue}

The adventitial layer of arteries is in close contact with adipocytes that form the perivascular adipose tissue (PVAT). PVAT is an important regulator of arterial function. It supports the blood vessel mechanically, by clearing FFA and by releasing paracrine factors that regulate vascular tone, inflammation, redox state, and smooth muscle cell proliferation (Costa et al. 2018). Given these multiple roles, it is not surprising that experimental stripping of arteries in rodents by mechanical or genetic means accelerates the development of atherosclerosis (Chang et al. 2012; Tian et al. 2013; Manka et al. 2014). Perivascular adipocytes may resemble white or brown adipocytes, depending on the anatomical location and the physiological state. For example, PVAT surrounding mesenteric arteries in mice was found to be similar to WAT (Gálvez-Prieto et al. 2008), whereas PVAT associated with the thoracic aorta contains brown-like adipocytes (Fitzgibbons et al. 2011). Of note, the latter adipocytes are functionally thermogenic, as they influence intravascular temperature in mice exposed to cold (Chang et al. 2012).

The quantity of PVAT in humans increases in obesity and is associated with cardiovascular disease (Britton et al. 2012). Mechanistic studies indicate that not only the volume but also altered properties of PVAT in obesity influence the development of atherosclerosis (Costa et al. 2018; Nosalski and Guzik 2017). One important alteration accelerating atheroma formation appears to be increased inflammation and infiltration of macrophages into PVAT (Henrichot et al. 2005; Skiba et al. 2017). Supporting this notion, expression of the pro-inflammatory molecule monocyte chemo-attractant protein-1 in transplanted PVAT is a determinant of neointima formation in a wire injury atherosclerosis model (Manka et al. 2014). Furthermore, PVAT-derived tumor necrosis factor- $\alpha$ is a causal factor for mitochondrial ROS production leading to aortic vasoconstriction in obese mice (Menezes da Costa et al. 2017). Inflammation promotes changes in the secretion of paracrine hormones from PVAT. For example, the release of adiponectin is reduced in obese, diabetic mice, leading to impaired insulin-dependent vasorelaxation (Meijer et al. 2013), whereas expression of the adipokine chemerin in PVAT confers vasoconstriction, and this is linked to obesity-induced hypertension (Ferland et al. 2018; Weng et al. 2017). These and several other hormones secreted by PVAT act as paracrine regulators of vascular tone, hypertension, and atherosclerosis (Nosalski and Guzik 2017) and thereby determine the health of arteries both under homeostatic and inflammatory circumstances (Figs. 1 and 2). 


\section{$3 \quad$ Therapies Targeting Adipose Tissue with Proven Clinical Efficacy in the Treatment of Atherosclerosis}

\subsection{Peroxisome Proliferator-Activated Receptor- $\gamma$ (PPAR $\gamma$ ) Agonists}

PPAR $\gamma$ agonists of the thiazolidinedione (TZD) class are insulin-sensitizing drugs used for the treatment of type 2 diabetes. PPAR $\gamma$ is a transcription factor critical for adipocyte differentiation, and WAT and BAT are the tissues with the highest expression. The main target for TZD-based diabetes therapy is dysfunctional hypertrophic adipose tissue where TZDs improve insulin signaling and lipid storage while inducing an anti-inflammatory adipokine profile. Together, these actions lead to less ectopic lipid deposition in liver and muscle and improved systemic insulin sensitivity (Yau et al. 2013). TZDs also have anti-atherogenic activity Saremi et al. 2013; Thorp et al. 2007. Whether these protective cardiovascular effects are mediated by PPAR $\gamma$ expressed in adipocytes, for example, through improved thermogenesis and anti-inflammation (Chang et al. 2018), is unclear as the transcription factor is also expressed and mediates anti-atherosclerotic effects in immune, smooth muscle and endothelial cells (Murakami-Nishida et al. 2019; Subramanian et al. 2010; Qu et al. 2012, Ozasa et al. 2011). Nevertheless, several prospective clinical studies showed an improved plasma lipoprotein profile, reduced carotid artery intima media thickness, fewer cardiovascular disease events, and lower mortality in patients treated with the TZD pioglitazone compared to controls (Hanefeld 2009; Yau et al. 2013, Sartemi et al. 2013). Unfortunately, adverse effects, especially fluid retention, congestive heart failure, and bladder cancer, at least some of them target-related (Yau et al. 2013, Devchand et al. 2018), can offset the desired actions of the drug.

\subsection{Niacin}

Niacin (nicotinic acid) is a vitamin that, when applied orally at high doses, reduces atherosclerosis and cardiovascular mortality, especially in patients with metabolic syndrome (Superko et al. 2017). One anti-atherosclerotic mechanism of niacin is the improvement of diabetic dyslipidemia, including reduction in triglycerides and small dense LDL as well as the raising of HDL cholesterol (Kühnast et al. 2013). Signaling through the most important niacin receptor HCA2 (GPR109A, HM74) in adipocytes lowers cyclic AMP and reduces lipolysis and, hence, release of FFA. A longstanding hypothesis is that this improves diabetic dyslipidemia, as the decreased FFA flux to the liver entails reduced hepatic VLDL triglyceride secretion (Zeman et al. 2016). This notion has, however, been challenged by a paper describing that in both mice and humans, niacin and synthetic HCA2 ligands acutely lower plasma FFA whereas only niacin reduces plasma triglycerides and LDL cholesterol while elevating HDL (Lauring et al. 2012). Thus, the beneficial effects of niacin on diabetic dyslipidemia are at least in part independent of HCA2-mediated lipolysis. Of note, HCA2 is expressed and mediates anti-inflammatory effects in other artery 
wall cell types, in particular macrophages, endothelial cells, and vascular smooth muscle cells (Graff et al. 2016). An important role of macrophages was suggested by a bone marrow transplantation study with LDLR-deficient $\left(\mathrm{Ldlr}^{--}\right)$mice. In this study, niacin was not able to suppress intimal macrophage recruitment and atheroma formation in wild-type acceptor mice that received HCA2-deficient cells, whereas transplantation of HCA2 wild-type hematopoietic cells restored niacin efficacy. This effect was independent of plasma lipid levels (Lukasova et al. 2011). Taken together, niacin has anti-atherogenic properties by improving plasma lipoprotein concentrations especially under diabetic conditions and probably by direct antiinflammatory effects on immune cells. In addition, niacin may exert antiatherosclerotic effects through HCA2 by increasing the secretion of adiponectin (Plaisance et al. 2009) and by suppressing pro-inflammatory mediators in adipocytes (Digby et al. 2010).

\subsection{Renin-Angiotensin System Blockade}

Inhibitors of the renin-angiotensin system (RAS) are widely prescribed drugs for hypertension, known to reduce atherosclerosis in humans and preclinical models, to some degree through their anti-inflammatory activity (Ranjbar et al. 2019). Of note, all components of the RAS are expressed in PVAT (Gálvez-Prieto et al. 2008), and pre-clinical models indicate a role of PVAT RAS in atherosclerosis. For example, angiotensin II was increased in periaortic adipose tissue but not in the circulation or other adipose tissues of Apoe ${ }^{-1-}$ mice with unilateral nephrectomy, a model of accelerated atherosclerosis. Of note, no increase in PVAT inflammatory markers was observed in the nephrectomized mice, and angiotensin receptor blockers (ARBs) reduced atheroma (Kawahito et al. 2013). In another study, aortic transplantation of PVAT from Apoe ${ }^{-l-}$ mice fed a high cholesterol diet increased atherosclerosis in acceptor mice, whereas transplantation of PVAT from angiotensin II type 1 receptor knockout mice or PVAT from ARB-treated mice reduced atheroma (Irie et al. 2015). Taken together, it is plausible that PVAT in part mediates the antiatherosclerotic efficacy of RAS inhibitors.

\section{Novel Therapeutic Targets in Adipose Tissue for Treatment of Atherosclerosis}

\subsection{Promoting Lipoprotein Disposal and Lipid Storage in Adipose Tissues}

WAT is a major site of TRL fatty acid disposal after a meal, and human studies showed that this process is frequently impaired in obese and diabetic subjects (Jacome-Sosa and Parks 2014; Kersten 2014). Improving TRL processing and lipid storage in white adipocytes is, therefore, a suitable approach to reduce plasma triglycerides and hence diabetic dyslipidemia. LPL is the gatekeeper of TRL disposal 
in adipose tissue. The activity of the dimeric enzyme is controlled in a complex manner at the level of gene expression, assembly, translocation from adipocytes to the capillary lumen, and interaction of LPL with TRL particles (Kersten 2014). Insulin is the most important positive regulator of LPL activity, whereas angiopoietin-like-4 (ANGPTL4) and APOC3 are prominent negative regulators in adipose tissues (Kersten 2014). APOC3 has attracted a lot of attention in recent years, because plasma concentrations of this abundant apolipoprotein are a major determinant of plasma triglycerides and cardiovascular risk in the human population (Jørgensen et al. 2014; Crosby et al. 2014), explained by APOC3 inhibiting LPL as well as hepatic endocytosis of TRL remnants (Ramms and Gordts 2018; Taskinen et al. 2019). Recently, it became clear that the effect of APOC3 on lipoprotein receptor inactivation seems to be more relevant than its anti-lipolytic action (Gordts et al. 2016), especially as antisense-based reduction of APOC 3 substantially lowered triglyceride levels in LPL-deficient patients (Gaudet et al. 2014). In addition to its role in dyslipidemia, APOC 3 appears to directly act on arteries and to facilitate subendothelial accumulation of atherogenic particles (Taskinen et al. 2019). Overall, downregulation of APOC 3 in the liver efficiently lowers triglycerides, and in part this effect is mediated via TRL disposal in adipose tissue.

ANGPTL4 negatively regulates LPL activity by preventing assembly of LPL and destabilizing the enzyme already during secretion from adipocytes (Dijk et al. 2018). Population-based genetic studies have consistently found reduced plasma triglycerides and reduced coronary artery disease risk in humans with a loss-offunction ANGPTL4 mutation (Bailetti et al. 2018; Stitziel et al. 2016; Dewey et al. 2016). A monoclonal antibody against ANGPTL4 suppressed plasma triglycerides in mice and monkeys (Dewey et al. 2016). Selective knockout of Angptl4 in brown adipocytes of mice reduced TRL disposal only in BAT (Singh et al. 2018), supporting the notion that targeting ANGPTL4 in adipose tissue can be a means to specifically control organ-specific LPL activity. Importantly, LPL itself is also a drug target. Small molecules that bind to and activate LPL were identified in pharmaceutical screening efforts (Tsutsumi et al. 1993; Geldenhuys et al. 2014).

Another method to increase TRL disposal in adipose tissue is fibroblast growth factor (FGF) 21. FGF21 is an endocrine FGF isoform that fine-tunes systemic glucose and lipid metabolism (Bondurant and Potthoff 2018). At pharmacological doses, it increases insulin sensitivity and lowers blood glucose as well as lipids in mice (Kharitonenkov et al. 2005). Of note, lowering of triglycerides, but not glucose, was the most prominent effect of FGF21 in phase 1b clinical studies (Gaich et al. 2013; Talukdar et al. 2016). Mechanistic studies in mice showed that pharmacologically administered FGF21 acutely lowers plasma triglycerides and FFA. Tracer studies with labeled lipids demonstrated that this was due to higher uptake into WAT and BAT but not into other organs (Schlein et al. 2016). This effect was observed for both TRL-associated and albumin-bound fatty acids, indicating that FGF21 acts at least in part through stimulating fatty acid transport into adipocytes (Schlein et al. 2016).

An alternative target to boost lipoprotein disposal in adipose tissue is $\mathrm{C}-\mathrm{X}-\mathrm{C}$ chemokine motif receptor-7 (CXCR7). CXCR7 is also known as atypical chemokine 
receptor-3, because it is not expressed in leukocytes (Berahovich et al. 2010). Cxcr $7^{-1-}$ Apoe $^{-/-}$mice on Western-type diet had exacerbated hypercholesterolemia and atherosclerosis, whereas the selective CXCR7 agonist CCX771 attenuated plaque formation in $\mathrm{Apoe}^{-/-}$mice ( $\mathrm{Li}$ et al. 2014). CCX771 treatment lowered plasma triglycerides and VLDL cholesterol, which could be explained by increased VLDL clearance in visceral WAT but not BAT or other organs. This depot specifically exhibited increased LPL activity and reduced ANGPTL4 (Li et al. 2014).

Taken together, several targets and therapeutic approaches have been identified for the stimulation of lipoprotein clearance in adipose tissue with the aim to lower the plasma levels of atherogenic lipoproteins.

\subsection{Boosting Thermogenic Activation}

Activated thermogenic adipose tissue takes up energy at a high rate, and, at least in mice, a majority of calories is provided by TRL (Heine et al. 2018). BAT activation was shown to improve diabetic dyslipidemia, to increase reverse cholesterol transport and reduce atherosclerosis in APOE3-Leiden-CETP mice, an atherosclerosisprone mouse model with humanized lipoprotein metabolism (Berbée et al. 2015; Bartelt et al. 2017). Reduction in atherosclerosis could be achieved by chronic $\beta 3$ adrenergic receptor ( $\beta 3-\mathrm{AR})$ stimulation using a synthetic agonist (Berbée et al. $2015)$, demonstrating feasibility of pharmacological intervention. Of note, the $\beta 3$ AR agonist mirabegron, an approved drug for overactive bladder, activates BAT in humans (Cypess et al. 2015), and chronic dosing with mirabegron induces WAT browning (Finlin et al. 2018). $\beta 3$-AR is highly expressed in adipocytes, and cardiovascular side effects of currently available $\beta 3$ agonists such as hypertension occur only at high doses and are in part due to cross-reactivity on $\beta 1$-ARs (Hainer 2016; Loh et al. 2019). Whether chronic BAT activation or induction of beige adipocytes by $\beta 3-\mathrm{AR}$ agonists is sufficient to improve diabetic dyslipidemia in humans needs to be shown and is currently under investigation. Importantly, boosting thermogenic adipocytes by $\beta 3$-AR agonists may counteract atherosclerosis independently of systemic lipoprotein metabolism via local activation of thermogenic adipocytes in PVAT. For example, a recent study demonstrated increased vascular temperature and reduced local inflammation in transgenic mice with higher thermogenic activity in PVAT (Xiong et al. 2017). Given that the common presence of BAT in adult humans has only been recognized recently (Celi 2009), it is likely that drugs directed at thermogenic adipose tissue targets other than $\beta 3-\mathrm{AR}$, such as adenosine $\mathrm{A}_{2 \mathrm{~A}}$ agonists (Gnad et al. 2014), will be developed in the future.

\subsection{Targeting Inflammation in Adipose Tissue}

Chronic, subclinical inflammation is a hallmark of insulin-resistant WAT in unhealthy obesity. Anti-inflammatory interventions in adipose tissue may slow or prevent the development of atherosclerosis by improving lipoprotein disposal, 
normalizing systemic glucose homeostasis, and changing the secretome of adipose tissues in a favorable way. General anti-inflammatory therapies can have beneficial cardiovascular effects, as demonstrated by neutralizing antibodies directed against $\mathrm{TNF} \alpha$ that reduce cardiovascular events in rheumatoid arthritis patients (Jacobsson et al. 2005) and raise plasma adiponectin levels (Nishida et al. 2008). Although immune cells are not organ-specific and found throughout the body, positive effects of many anti-inflammation therapies are likely to be at least in part mediated via inflammation in adipose tissue. This is especially true for PVAT that is in close proximity with atherosclerosis-prone arteries and exhibits a profound infiltration of macrophages, T-lymphocytes, and other immune cells during initiation and progression of atherosclerosis (Akoumianakis et al. 2017). Many anti-inflammatory proteins can be targeted in PVAT and have the potential to prevent and reduce atherosclerosis, as suggested by rodent studies. For example, the angiotensin 1-7 analogue AVE0991 that signals through the receptor Mas was demonstrated to selectively suppress inflammation in PVAT and reduce atherosclerosis in Apo $e^{-1-}$ mice (Skiba et al. 2017). Receptors of the chemokine RANTES (CCL5) are associated with PVAT inflammation, and $C \mathrm{Cl} 5^{-1-}$ mice are protected from perivascular inflammation (Mikolajczyk et al. 2016), while the RANTES receptor antagonist met-RANTES suppresses atherosclerosis in $\mathrm{Ldlr}^{-1-}$ mice (Veillard et al. 2004). Similarly, CXCL10 signaling regulates $\mathrm{T}$ cell infiltration in atherosclerosis, and genetic deficiency of the CXCL10 receptor CXCR3 (Veillard et al. 2005) or treatment with the CXCR3 antagonist NBI-74330 (van Wanrooij et al. 2008) attenuates atherosclerosis in hypercholesterolemic mice. Several other chemokines appear to play an important role in PVAT inflammation and atherosclerosis (Nosalski and Guzik 2017). Taken together, several promising targets to tackle atherosclerosis by reducing inflammation in adipose tissue depots have been identified in mouse experiments. Whether anti-atherosclerotic approaches targeting adipose tissue inflammation with proof of concept in rodents can be translated into human therapies needs, however, to be shown.

\subsection{Hormones Derived from Thermogenic Adipose Tissue}

Compared to WAT, BAT and other thermogenic fat depots have a small mass and thus are probably a minor source of most circulating adipokines. However, there are exceptions to the rule, and some hormones are enriched in BAT (Villarroya et al. 2017). Recent studies suggest that some of these hormones are potential targets to prevent or treat atherosclerosis. For example, transplantation of BAT into the visceral cavity of $A p o e^{-/-}$mice led to reduction in atherosclerotic plaque size. This was accompanied by increased plasma FGF21 and adiponectin, and the beneficial effect of BAT transplantation in this study could be blocked by $\beta 3$-AR antagonists (Kikai et al. 2018). Many anti-atherogenic activities of FGF21 have been identified in rodents (Jin et al. 2016; Domouzoglou et al. 2015). Therefore, it is plausible that elevated FGF21 mediates at least some of the effects in this model. Of note, adenosine $\mathrm{A}_{2 \mathrm{~A}}$ receptor agonists, molecules that activate thermogenic 
adipocytes in mice and humans (Gnad et al. 2014), were found to trigger FGF21 expression and secretion from BAT, and this was important to prevent hypertensioninduced cardiac hypertrophy (Ruan et al. 2018). Thus, at least in mice, activated BAT is a meaningful source of cardio-protective and anti-atherosclerotic FGF21.

Moreover, the peptide neuregulin-4 and the linoleic acid derivative 12,13dihydroxy-9Z-octadecenoic acid (diHOME) have recently been described as hormones enriched in and released by activated thermogenic adipocytes. They act in a paracrine fashion to potentiate thermogenic function and appear to exhibit beneficial metabolic functions in the liver and muscle (Nugroho et al. 2018; Stanford et al. 2018; Pellegrinelli et al. 2018; Guo et al. 2017; Lynes et al. 2017; Wang et al. 2014). It is tempting to speculate that these, and other pro-thermogenic hormones secreted by brown and beige adipocytes such as $\mathrm{C}-\mathrm{X}-\mathrm{C}$ motif chemokine ligand-14 (Cereijo et al. 2018), have a protective effect in atherosclerosis, for example, by increasing lipoprotein disposal or by modulating inflammation.

\subsection{De Novo Lipogenesis-Derived Lipokines}

Adipose tissue is a quantitatively relevant site of de novo lipogenesis (DNL), the endogenous synthesis of fatty acids from non-lipid precursors. One important feature of unhealthy obesity is increased DNL in the liver accompanied by decreased DNL in WAT (Eissing et al. 2013). Elevated hepatic DNL promotes insulin resistance and is a mechanism that worsens diabetic dyslipidemia by increasing triglyceride availability for VLDL production (Scheja and Heeren 2016). How decreased WAT DNL contributes to the development of metabolic disease has long been elusive. Research of the recent years has provided strong evidence that DNL-associated lipids secreted from adipocytes, coined lipokines, are part of the mechanism. The first lipokine to be identified was the FFA variant of palmitoleate (C16:1n-7), a major fatty acid produced by DNL that was found to be reduced in WAT of obese mice. Palmitoleate FFA turned out to be an anti-inflammatory, insulin-sensitizing molecule that improves systemic glucose homeostasis in mice (Cao et al. 2008). Palmitoleate was identified to reduce atherosclerosis via suppressing pro-inflammatory differentiation of macrophages, and Apoe $e^{-1-}$ mice on a Western-type diet supplemented with palmitoleate had significantly reduced plaque size compared to control mice (Çimen et al. 2016; Yang et al. 2019). Thus, WAT-derived palmitoleate can reduce atherosclerosis risk by modulating inflammation. It is important to note that WAT-derived palmitoleate is not or only marginally lower in obese, insulin-resistant compared to healthy humans (Eissing et al. 2013; Stefan et al. 2010). Nevertheless, dietary palmitoleate supplementation decreased inflammation and lowered LDL in human subjects (Bueno-Hernández et al. 2017; Bernstein et al. 2014), highlighting the anti-atherosclerosis potential of palmitoleate.

Other lipids proposed as adipose tissue-derived DNL-associated lipokines are fatty acid esters of hydroxy fatty acids (FAHFAs), a novel class of lipids (Yore et al. 2014). WAT levels of certain FAHFA species were shown to depend on DNL. Moreover, circulating levels of DNL-linked FAHFA were shown to be tightly 
associated with insulin sensitivity in mice and in humans (Yore et al. 2014; Hammarstedt et al. 2018). In addition, oral FAHFA supplementation was demonstrated to improve glucose tolerance in mice (Yore et al. 2014), an FAHFA effect that has, however, been questioned by another group (Pflimlin et al. 2018). More research is warranted, especially with regard to FAHFA synthesis and degradation as well as FAHFA signaling mechanisms to better understand the role of this novel lipid class in metabolic regulation. Furthermore, studies addressing the association of DNL-derived FAHFAs with cardiovascular risk markers are needed to find out whether FAHFAs modulate the development of cardiovascular disease.

\section{$5 \quad$ Future Directions}

In the past decades, many adipokines, chemokines, and other regulatory molecules acting on or derived from adipose tissues that affect the development and progression of atherosclerosis have been identified. One major task will be to successfully translate these findings into the clinics. In some cases such as pioglitazone, cardiovascular clinical benefit is evident; however, adverse effects in other organs have precluded more widespread use or even led to the retraction of the drug. Here, adipose tissue targeted delivery using advanced drug delivery technologies could be a solution. Peptides that selectively bind to endothelium in WAT (Kolonin et al. 2004) and BAT (Azhdarinia et al. 2013), respectively, have been identified, and the WAT-selective peptide was successfully used for WAT-specific drug delivery (Xue et al. 2016). Although this WAT-directed drug delivery system is not suitable for oral application, proof of concept that adipose tissue depots can be targeted specifically was delivered.

Methods to achieve adipose-directed delivery of nucleic acids with the goal to overexpress a beneficial protein, or to modulate endogenous RNA levels, have been considerably advanced in the past years. For example, adipose tissue-directed expression of genes, or suppression using small hairpin RNAs, can be achieved by the means of adeno-associated virus vectors ( $\mathrm{O}^{\prime} \mathrm{Neill}$ et al. 2014). Another promising approach is the delivery of silencing RNAs encapsulated by glucan shells, a method that specifically delivers the regulatory RNA species to WAT macrophages (Aouadi et al. 2013).

An alternative approach to molecular interventions in unhealthy adipose tissues would be the development of regenerative medicines based on bioelectric stimulation devices to increase the sympathetic tone in specific adipose depots or gene therapy and cell transplantation to restore functional adipocytes. Such innovative concepts and highly advanced technologies would provide a novel therapeutic strategy to target obesity-associated cardiovascular disease. 


\section{References}

Akoumianakis I, Tarun A, Antoniades C (2017) Perivascular adipose tissue as a regulator of vascular disease pathogenesis: identifying novel therapeutic targets. $\mathrm{Br} \mathrm{J}$ Pharmacol 174:3411-3424

Aouadi M, Tencerova M, Vangala P, Yawe JC, Nicoloro SM, Amano SU, Cohen JL, Czech MP (2013) Gene silencing in adipose tissue macrophages regulates whole-body metabolism in obese mice. Proc Natl Acad Sci U S A 110:8278-8283

Azhdarinia A, Daquinag AC, Tseng C, Ghosh SC, Ghosh P, Amaya-Manzanares F, SevickMuraca E, Kolonin MG (2013) A peptide probe for targeted brown adipose tissue imaging. Nat Commun 4:2472

Bailetti D, Bertoccini L, Mancina RM, Barchetta I, Capoccia D, Cossu E, Pujia A, Lenzi A, Leonetti F, Cavallo MG, Romeo S, Baroni MG (2018) ANGPTL4 gene E40K variation protects against obesity-associated dyslipidemia in participants with obesity. Obes Sci Pract 5:83-90

Bartelt A, Heeren J (2014) Adipose tissue browning and metabolic health. Nat Rev Endocrinol 10:24-36

Bartelt A, Bruns OT, Reimer R, Hohenberg H, Ittrich H, Peldschus K, Kaul MG, Tromsdorf UI, Weller H, Waurisch C, Eychmüller A, Gordts PL, Rinninger F, Bruegelmann K, Freund B, Nielsen P, Merkel M, Heeren J (2011) Brown adipose tissue activity controls triglyceride clearance. Nat Med 17:200-205

Bartelt A, John C, Schaltenberg N, Berbée JFP, Worthmann A, Cherradi ML, Schlein C, Piepenburg J, Boon MR, Rinninger F, Heine M, Toedter K, Niemeier A, Nilsson SK, Fischer M, Wijers SL, van Marken LW, Scheja L, Rensen PCN, Heeren J (2017) Thermogenic adipocytes promote HDL turnover and reverse cholesterol transport. Nat Commun 8:15010

Becher T, Palanisamy S, Kramer DJ, Marx SJ, Wibmer AG, Del Gaudio I, Butler SD, Jiang CS, Vaughan R, Schöder H et al (2020) Brown adipose tissue is associated with improved cardiometabolic health and regulates blood pressure. bioRxiv, 2020.2002.2008.933754

Berahovich RD, Zabel BA, Penfold ME, Lewén S, Wang Y, Miao Z, Gan L, Pereda J, Dias J, Slukvin II, McGrath KE, Jaen JC, Schall TJ (2010) CXCR7 protein is not expressed on human or mouse leukocytes. J Immunol 185:5130-5139

Berbée JF, Boon MR, Khedoe PP, Bartelt A, Schlein C, Worthmann A, Kooijman S, Hoeke G, Mol IM, John C, Jung C, Vazirpanah N, Brouwers LP, Gordts PL, Esko JD, Hiemstra PS, Havekes LM, Scheja L, Heeren J, Rensen PC (2015) Brown fat activation reduces hypercholesterolaemia and protects from atherosclerosis development. Nat Commun 6:6356

Bernstein AM, Roizen MF, Martinez L (2014) Purified palmitoleic acid for the reduction of highsensitivity C-reactive protein and serum lipids: a double-blinded, randomized, placebo controlled study. J Clin Lipidol 8:612-617

BonDurant LD, Potthoff MJ (2018) Fibroblast growth factor 21: a versatile regulator of metabolic homeostasis. Annu Rev Nutr 38:173-196

Bordicchia M, Liu D, Amri EZ, Ailhaud G, Dessì-Fulgheri P, Zhang C, Takahashi N, Sarzani R, Collins S (2012) Cardiac natriuretic peptides act via p38 MAPK to induce the brown fat thermogenic program in mouse and human adipocytes. J Clin Invest 122:1022-1036

Britton KA, Pedley A, Massaro JM, Corsini EM, Murabito JM, Hoffmann U, Fox CS (2012) Prevalence, distribution, and risk factor correlates of high thoracic periaortic fat in the Framingham heart study. J Am Heart Assoc 1:e004200

Bueno-Hernández N, Sixtos-Alonso MS, Milke García MDP, Yamamoto-Furusho JK (2017) Effect of Cis-palmitoleic acid supplementation on inflammation and expression of HNF4 $\gamma, \mathrm{HNF} 4 \alpha$ and IL6 in patients with ulcerative colitis. Minerva Gastroenterol Dietol 63:257-263

Cannon B, Nedergaard J (2004) Brown adipose tissue: function and physiological significance. Physiol Rev 84:277-359

Cao H, Gerhold K, Mayers JR, Wiest MM, Watkins SM, Hotamisligil GS (2008) Identification of a lipokine, a lipid hormone linking adipose tissue to systemic metabolism. Cell 134:933-944

Celi FS (2009) Brown adipose tissue--when it pays to be inefficient. N Engl J Med 360:1553-1556 
Cereijo R, Gavalda-Navarro A, Cairo M, Quesada-López T, Villarroya J, Morón-Ros S, SánchezInfantes D, Peyrou M, Iglesias R, Mampel T, Turatsinze JV, Eizirik DL, Giralt M, Villarroya F (2018) CXCL14, a brown adipokine that mediates brown-fat-to-macrophage communication in thermogenic adaptation. Cell Metab 28:750-763

Chang L, Villacorta L, Li R, Hamblin M, Xu W, Dou C, Zhang J, Wu J, Zeng R, Chen YE (2012) Loss of perivascular adipose tissue on peroxisome proliferator-activated receptor- $\gamma$ deletion in smooth muscle cells impairs intravascular thermoregulation and enhances atherosclerosis. Circulation 126:1067-1078

Chang L, Zhao X, Garcia-Barrio M, Zhang J, Eugene Chen Y (2018) MitoNEET in perivascular adipose tissue prevents arterial stiffness in aging mice. Cardiovasc Drugs Ther 32:531-539

Çimen I, Kocatürk B, Koyuncu S, Tufanlı Ö, Onat UI, Yıldırım AD, Apaydın O, Demirsoy Ş, Aykut ZG, Nguyen UT, Watkins SM, Hotamışligil GS, Erbay E (2016) Prevention of atherosclerosis by bioactive palmitoleate through suppression of organelle stress and inflammasome activation. Sci Transl Med 8:358ra126

Cinti S (2001) The adipose organ: morphological perspectives of adipose tissues. Proc Nutr Soc 60:319-328

Costa RM, Neves KB, Tostes RC, Lobato NS (2018) Perivascular adipose tissue as a relevant fat depot for cardiovascular risk in obesity. Front Physiol 9:253

Crewe C, An YA, Scherer PE (2017) The ominous triad of adipose tissue dysfunction: inflammation, fibrosis, and impaired angiogenesis. J Clin Invest 127:74-82

Crosby J, Peloso GM, Auer PL, Crosslin DR, Stitziel NO, Lange LA, Lu Y, Tang ZZ, Zhang H, Hindy G, Masca N, Stirrups K, Kanoni S, Do R, Jun G, Hu Y, Kang HM, Xue C, Goel A, Farrall M, Duga S, Merlini PA, Asselta R, Girelli D, Olivieri O, Martinelli N, Yin W, Reilly D, Speliotes E, Fox CS, Hveem K, Holmen OL, Nikpay M, Farlow DN, Assimes TL, Franceschini N, Robinson J, North KE, Martin LW, DePristo M, Gupta N, Escher SA, Jansson JH, Van Zuydam N, Palmer CN, Wareham N, Koch W, Meitinger T, Peters A, Lieb W, Erbel R, Konig IR, Kruppa J, Degenhardt F, Gottesman O, Bottinger EP, O'Donnell CJ, Psaty BM, Ballantyne CM, Abecasis G, Ordovas JM, Melander O, Watkins H, Orho-Melander M, Ardissino D, Loos RJ, McPherson R, Willer CJ, Erdmann J, Hall AS, Samani NJ, Deloukas P, Schunkert H, Wilson JG, Kooperberg C, Rich SS, Tracy RP, Lin DY, Altshuler D, Gabriel S, Nickerson DA, Jarvik GP, Cupples LA, Reiner AP, Boerwinkle E, Kathiresan S (2014) Loss-of-function mutations in APOC3, triglycerides, and coronary disease. N Engl J Med 371:22-31

Cypess AM, Weiner LS, Roberts-Toler C, Franquet Elía E, Kessler SH, Kahn PA, English J, Chatman K, Trauger SA, Doria A, Kolodny GM (2015) Activation of human brown adipose tissue by a $\beta 3$-adrenergic receptor agonist. Cell Metab 21:33-38

Devchand PR, Liu T, Altman RB, FitzGerald GA, Schadt EE (2018) The pioglitazone trek via human PPAR gamma: from discovery to a medicine at the FDA and beyond. Front Pharmacol 9:1093

Dewey FE, Gusarova V, O'Dushlaine C, Gottesman O, Trejos J, Hunt C, Van Hout CV, Habegger L, Buckler D, Lai KM, Leader JB, Murray MF, Ritchie MD, Kirchner HL, Ledbetter DH, Penn J, Lopez A, Borecki IB, Overton JD, Reid JG, Carey DJ, Murphy AJ, Yancopoulos GD, Baras A, Gromada J, Shuldiner AR (2016) Inactivating variants in ANGPTL4 and risk of coronary artery disease. N Engl J Med 374:1123-1133

Digby JE, McNeill E, Dyar OJ, Lam V, Greaves DR, Choudhury RP (2010) Anti-inflammatory effects of nicotinic acid in adipocytes demonstrated by suppression of fractalkine, RANTES, and MCP-1 and upregulation of adiponectin. Atherosclerosis 209:89-95

Dijk W, Ruppert PMM, Oost LJ, Kersten S (2018) Angiopoietin-like 4 promotes the intracellular cleavage of lipoprotein lipase by PCSK3/furin in adipocytes. J Biol Chem 293:14134-14145

Domouzoglou EM, Naka KK, Vlahos AP, Papafaklis MI, Michalis LK, Tsatsoulis A, Maratos-Flier E (2015) Fibroblast growth factors in cardiovascular disease: the emerging role of FGF21. Am J Physiol Heart Circ Physiol 309:H1029-H1038 
Eissing L, Scherer T, Tödter K, Knippschild U, Greve JW, Buurman WA, Pinnschmidt HO, Rensen SS, Wolf AM, Bartelt A, Heeren J, Buettner C, Scheja L (2013) De novo lipogenesis in human fat and liver is linked to ChREBP- $\beta$ and metabolic health. Nat Commun 4:1528

Ferland DJ, Seitz B, Darios ES, Thompson JM, Yeh ST, Mullick AE, Watts SW (2018) Wholebody but not hepatic knockdown of Chemerin by antisense oligonucleotide decreases blood pressure in rats. J Pharmacol Exp Ther 365:212-218

Finlin BS, Memetimin H, Confides AL, Kasza I, Zhu B, Vekaria HJ, Harfmann B, Jones KA, Johnson ZR, Westgate PM, Alexander CM, Sullivan PG, Dupont-Versteegden EE, Kern PA (2018) Human adipose beiging in response to cold and mirabegron. JCI Insight 3:121510

Fitzgibbons TP, Kogan S, Aouadi M, Hendricks GM, Straubhaar J, Czech MP (2011) Similarity of mouse perivascular and brown adipose tissues and their resistance to diet-induced inflammation. Am J Physiol Heart Circ Physiol 301:H1425-H1437

Gaich G, Chien JY, Fu H, Glass LC, Deeg MA, Holland WL, Kharitonenkov A, Bumol T, Schilske HK, Moller DE (2013) The effects of LY2405319, an FGF21 analog, in obese human subjects with type 2 diabetes. Cell Metab 18:333-340

Gálvez-Prieto B, Bolbrinker J, Stucchi P, de Las Heras AI, Merino B, Arribas S, Ruiz-Gayo M, Huber M, Wehland M, Kreutz R, Fernandez-Alfonso MS (2008) Comparative expression analysis of the renin-angiotensin system components between white and brown perivascular adipose tissue. J Endocrinol 197:55-64

Gaudet D, Brisson D, Tremblay K, Alexander VJ, Singleton W, Hughes SG, Geary RS, Baker BF, Graham MJ, Crooke RM, Witztum JL (2014) Targeting APOC3 in the familial chylomicronemia syndrome. N Engl J Med 371:2200-2206

Geldenhuys WJ, Aring D, Sadana P (2014) A novel lipoprotein lipase (LPL) agonist rescues the enzyme from inhibition by angiopoietin-like 4 (ANGPTL4). Bioorg Med Chem Lett 24:2163-2167

Gnad T, Scheibler S, von Kügelgen I, Scheele C, Kilić A, Glöde A, Hoffmann LS, Reverte-Salisa L, Horn P, Mutlu S, El-Tayeb A, Kranz M, Deuther-Conrad W, Brust P, Lidell ME, Betz MJ, Enerbäck S, Schrader J, Yegutkin GG, Müller CE, Pfeifer A (2014) Adenosine activates brown adipose tissue and recruits beige adipocytes via A2A receptors. Nature 516:395-399

Gordts PL, Nock R, Son NH, Ramms B, Lew I, Gonzales JC, Thacker BE, Basu D, Lee RG, Mullick AE, Graham MJ, Goldberg IJ, Crooke RM, Witztum JL, Esko JD (2016) ApoC-III inhibits clearance of triglyceride-rich lipoproteins through LDL family receptors. J Clin Invest 126:2855-2866

Graff EC, Fang H, Wanders D, Judd RL (2016) Anti-inflammatory effects of the hydroxycarboxylic acid receptor 2. Metabolism 65:102-113

Guo L, Zhang P, Chen Z, Xia H, Li S, Zhang Y, Kobberup S, Zou W, Lin JD (2017) Hepatic neuregulin 4 signaling defines an endocrine checkpoint for steatosis-to-NASH progression. $\mathrm{J}$ Clin Invest 127:4449-4461

Hainer V (2016) Beta3-adrenoreceptor agonist mirabegron - a potential antiobesity drug? Expert Opin Pharmacother 17:2125-2127

Hammarstedt A, Syed I, Vijayakumar A, Eliasson B, Gogg S, Kahn BB, Smith U (2018) Adipose tissue dysfunction is associated with low levels of the novel palmitic acid hydroxystearic acids. Sci Rep 8:15757

Hanefeld M (2009) The role of pioglitazone in modifying the atherogenic lipoprotein profile. Diabetes Obes Metab 11:742-756

Heine M, Fischer AW, Schlein C, Jung C, Straub LG, Gottschling K, Mangels N, Yuan Y, Nilsson SK, Liebscher G, Chen O, Schreiber R, Zechner R, Scheja L, Heeren J (2018) Lipolysis triggers a systemic insulin response essential for efficient energy replenishment of activated brown adipose tissue in mice. Cell Metab 28:644-655

Henrichot E, Juge-Aubry CE, Pernin A, Pache JC, Velebit V, Dayer JM, Meda P, Chizzolini C, Meier CA (2005) Production of chemokines by perivascular adipose tissue: a role in the pathogenesis of atherosclerosis? Arterioscler Thromb Vasc Biol 25:2594-2599 
Irie D, Kawahito H, Wakana N, Kato T, Kishida S, Kikai M, Ogata T, Ikeda K, Ueyama T, Matoba S, Yamada H (2015) Transplantation of periaortic adipose tissue from angiotensin receptor blocker-treated mice markedly ameliorates atherosclerosis development in apoE-/mice. J Renin-Angiotensin-Aldosterone Syst 16:67-78

Jacobsson LT, Turesson C, Gülfe A, Kapetanovic MC, Petersson IF, Saxne T, Geborek P (2005) Treatment with tumor necrosis factor blockers is associated with a lower incidence of first cardiovascular events in patients with rheumatoid arthritis. J Rheumatol 32:1213

Jacome-Sosa MM, Parks EJ (2014) Fatty acid sources and their fluxes as they contribute to plasma triglyceride concentrations and fatty liver in humans. Curr Opin Lipidol 25:213-220

Jin L, Lin Z, Xu A (2016) Fibroblast growth factor 21 protects against atherosclerosis via finetuning the multiorgan crosstalk. Diabetes Metab J 40:22-31

Jørgensen AB, Frikke-Schmidt R, Nordestgaard BG, Tybjærg-Hansen A (2014) Loss-of-function mutations in APOC3 and risk of ischemic vascular disease. N Engl J Med 371:32-41

Kawahito H, Yamada H, Irie D, Kato T, Akakabe Y, Kishida S, Takata H, Wakana N, Ogata T, Ikeda K, Ueyama T, Matoba S, Mori Y, Matsubara H (2013) Periaortic adipose tissue-specific activation of the renin-angiotensin system contributes to atherosclerosis development in uninephrectomized apoE-/- mice. Am J Physiol Heart Circ Physiol 305:H667-H675

Kersten S (2014) Physiological regulation of lipoprotein lipase. Biochim Biophys Acta 1841:919-933

Kharitonenkov A, Shiyanova TL, Koester A, Ford AM, Micanovic R, Galbreath EJ, Sandusky GE, Hammond LJ, Moyers JS, Owens RA, Gromada J, Brozinick JT, Hawkins ED, Wroblewski VJ, Li DS, Mehrbod F, Jaskunas SR, Shanafelt AB (2005) FGF-21 as a novel metabolic regulator. J Clin Invest 115:1627-1635

Kikai M, Yamada H, Wakana N, Terada K, Yamamoto K, Wada N, Motoyama S, Saburi M, Sugimoto T, Irie D, Kato T, Kawahito H, Ogata T, Matoba S (2018) Adrenergic receptormediated activation of FGF-21-adiponectin axis exerts atheroprotective effects in brown adipose tissue-transplanted apoE-/- mice. Biochem Biophys Res Commun 497:1097-1103

Klöting N, Fasshauer M, Dietrich A, Kovacs P, Schön MR, Kern M, Stumvoll M, Blüher M (2010) Insulin-sensitive obesity. Am J Physiol Endocrinol Metab 299:E506-E515

Kolonin MG, Saha PK, Chan L, Pasqualini R, Arap W (2004) Reversal of obesity by targeted ablation of adipose tissue. Nat Med 10:625-632

Kotzbeck P, Giordano A, Mondini E, Murano I, Severi I, Venema W, Cecchini MP, Kershaw EE, Barbatelli G, Haemmerle G, Zechner R, Cinti S (2018) Brown adipose tissue whitening leads to brown adipocyte death and adipose tissue inflammation. J Lipid Res 59:784-794

Kühnast S, Louwe MC, Heemskerk MM, Pieterman EJ, van Klinken JB, van den Berg SA, Smit JW, Havekes LM, Rensen PC, van der Hoorn JW, Princen HM, Jukema JW (2013) Niacin reduces atherosclerosis development in APOE $* 3$ Leiden.CETP mice mainly by reducing NonHDL-cholesterol. PLoS One 8:e66467

Lauring B, Taggart AK, Tata JR, Dunbar R, Caro L, Cheng K, Chin J, Colletti SL, Cote J, Khalilieh S, Liu J, Luo WL, Maclean AA, Peterson LB, Polis AB, Sirah W, Wu TJ, Liu X, Jin L, Wu K, Boatman PD, Semple G, Behan DP, Connolly DT, Lai E, Wagner JA, Wright SD, Cuffie C, Mitchel YB, Rader DJ, Paolini JF, Waters MG, Plump A (2012) Niacin lipid efficacy is independent of both the niacin receptor GPR109A and free fatty acid suppression. Sci Transl Med 4:148ra115

Li X, Zhu M, Penfold ME, Koenen RR, Thiemann A, Heyll K, Akhtar S, Koyadan S, Wu Z, Gremse F, Kiessling F, van Zandvoort M, Schall TJ, Weber C, Schober A (2014) Activation of CXCR7 limits atherosclerosis and improves hyperlipidemia by increasing cholesterol uptake in adipose tissue. Circulation 129:1244-1253

Lim S, Meigs JB (2014) Links between ectopic fat and vascular disease in humans. Arterioscler Thromb Vasc Biol 34:1820-1826

Loh RKC, Formosa MF, La Gerche A, Reutens AT, Kingwell BA, Carey AL (2019) Acute metabolic and cardiovascular effects of mirabegron in healthy individuals. Diabetes Obes Metab 21:276-284 
Lukasova M, Malaval C, Gille A, Kero J, Offermanns S (2011) Nicotinic acid inhibits progression of atherosclerosis in mice through its receptor GPR109A expressed by immune cells. J Clin Invest 121:1163-1173

Lynes MD, Leiria LO, Lundh M, Bartelt A, Shamsi F, Huang TL, Takahashi H, Hirshman MF, Schlein C, Lee A, Baer LA, May FJ, Gao F, Narain NR, Chen EY, Kiebish MA, Cypess AM, Blüher M, Goodyear LJ, Hotamisligil GS, Stanford KI, Tseng YH (2017) The cold-induced lipokine 12,13-diHOME promotes fatty acid transport into brown adipose tissue. Nat Med 23:631-637

Manka D, Chatterjee TK, Stoll LL, Basford JE, Konaniah ES, Srinivasan R, Bogdanov VY, Tang Y, Blomkalns AL, Hui DY, Weintraub NL (2014) Transplanted perivascular adipose tissue accelerates injury-induced neointimal hyperplasia: role of monocyte chemoattractant protein-1. Arterioscler Thromb Vasc Biol 34:1723-1730

Meijer RI, Bakker W, Alta CL, Sipkema P, Yudkin JS, Viollet B, Richter EA, Smulders YM, van Hinsbergh VW, Serné EH, Eringa EC (2013) Perivascular adipose tissue control of insulininduced vasoreactivity in muscle is impaired in $\mathrm{db} / \mathrm{db}$ mice. Diabetes 62:590-598

Menezes da Costa R, Fais RS, Dechandt CRP, Louzada-Junior P, Alberici LC, Lobato NS, Tostes RC (2017) Increased mitochondrial ROS generation mediates the loss of the anti-contractile effects of perivascular adipose tissue in high-fat diet obese mice. Br J Pharmacol 174:35273541

Mikolajczyk TP, Nosalski R, Szczepaniak P, Budzyn K, Osmenda G, Skiba D, Sagan A, Wu J, Vinh A, Marvar PJ, Guzik B, Podolec J, Drummond G, Lob HE, Harrison DG, Guzik TJ (2016) Role of chemokine RANTES in the regulation of perivascular inflammation, T-cell accumulation, and vascular dysfunction in hypertension. FASEB J 30:1987-1999

Murakami-Nishida S, Matsumura T, Senokuchi T, Ishii N, Kinoshita H, Yamada S, Morita Y, Nishida S, Motoshima H, Kondo T, Komohara Y, Araki E (2019) Pioglitazone suppresses macrophage proliferation in apolipoprotein-E deficient mice by activating PPAR $\gamma$. Atherosclerosis 286:30-39

Nishida K, Okada Y, Nawata M, Saito K, Tanaka Y (2008) Induction of hyperadiponectinemia following long-term treatment of patients with rheumatoid arthritis with infliximab (IFX), an anti-TNF-alpha antibody. Endocr J 55:213-216

Nosalski R, Guzik TJ (2017) Perivascular adipose tissue inflammation in vascular disease. Br J Pharmacol 174:3496-3513

Nugroho DB, Ikeda K, Barinda AJ, Wardhana DA, Yagi K, Miyata K, Oike Y, Hirata KI, Emoto N (2018) Neuregulin-4 is an angiogenic factor that is critically involved in the maintenance of adipose tissue vasculature. Biochem Biophys Res Commun 503:378-384

O'Neill SM, Hinkle C, Chen SJ, Sandhu A, Hovhannisyan R, Stephan S, Lagor WR, Ahima RS, Johnston JC, Reilly MP (2014) Targeting adipose tissue via systemic gene therapy. Gene Ther 21:653-661

Ozasa H, Ayaori M, Iizuka M, Terao Y, Uto-Kondo H, Yakushiji E, Takiguchi S, Nakaya K, Hisada T, Uehara Y, Ogura M, Sasaki M, Komatsu T, Horii S, Mochizuki S, Yoshimura M, Ikewaki K (2011) Pioglitazone enhances cholesterol efflux from macrophages by increasing ABCA1/ABCG1 expressions via PPAR $\gamma / \mathrm{LXR} \alpha$ pathway: findings from in vitro and ex vivo studies. Atherosclerosis 219:141-150

Pellegrinelli V, Peirce VJ, Howard L, Virtue S, Türei D, Senzacqua M, Frontini A, Dalley JW, Horton AR, Bidault G, Severi I, Whittle A, Rahmouni K, Saez-Rodriguez J, Cinti S, Davies AM, Vidal-Puig A (2018) Adipocyte-secreted BMP8b mediates adrenergic-induced remodeling of the neuro-vascular network in adipose tissue. Nat Commun 9:4974

Petersen MC, Shulman GI (2018) Mechanisms of insulin action and insulin resistance. Physiol Rev 98:2133-2223

Pflimlin E, Bielohuby M, Korn M, Breitschopf K, Löhn M, Wohlfart P, Konkar A, Podeschwa M, Bärenz F, Pfenninger A, Schwahn U, Opatz T, Reimann M, Petry S, Tennagels N (2018) Acute and repeated treatment with 5-PAHSA or 9-PAHSA isomers does not improve glucose control in mice. Cell Metab 28:217-227 
Plaisance EP, Lukasova M, Offermanns S, Zhang Y, Cao G, Judd RL (2009) Niacin stimulates adiponectin secretion through the GPR109A receptor. Am J Physiol Endocrinol Metab 296: E549-E558

Qu A, Shah YM, Manna SK, Gonzalez FJ (2012) Disruption of endothelial peroxisome proliferatoractivated receptor $\gamma$ accelerates diet-induced atherogenesis in LDL receptor-null mice. Arterioscler Thromb Vasc Biol 32:65-73

Ramms B, Gordts PLSM (2018) Apolipoprotein C-III in triglyceride-rich lipoprotein metabolism. Curr Opin Lipidol 29:171-179

Ranjbar R, Shafiee M, Hesari A, Ferns GA, Ghasemi F, Avan A (2019) The potential therapeutic use of renin-angiotensin system inhibitors in the treatment of inflammatory diseases. J Cell Physiol 234:2277-2295

Ruan CC, Kong LR, Chen XH, Ma Y, Pan XX, Zhang ZB, Gao PJ (2018) A2A receptor activation attenuates hypertensive cardiac remodeling via promoting Brown adipose tissue-derived FGF21. Cell Metab 28:476-489

Saremi A, Schwenke DC, Buchanan TA, Hodis HN, Mack WJ, Banerji M, Bray GA, Clement SC, Henry RR, Kitabchi AE, Mudaliar S, Ratner RE, Stentz FB, Musi N, Tripathy D, DeFronzo RA, Reaven PD (2013) Pioglitazone slows progression of atherosclerosis in prediabetes independent of changes in cardiovascular risk factors. Arterioscler Thromb Vasc Biol 33:393-399

Scheja L, Heeren J (2016) Metabolic interplay between white, beige, brown adipocytes and the liver. J Hepatol 64:1176-1186

Scheja L, Heeren J (2019) The endocrine function of adipose tissues in health and cardiometabolic disease. Nat Rev Endocrinol 15:507, manuscript in press

Schlein C, Talukdar S, Heine M, Fischer AW, Krott LM, Nilsson SK, Brenner MB, Heeren J, Scheja L (2016) FGF21 lowers plasma triglycerides by accelerating lipoprotein catabolism in white and brown adipose tissues. Cell Metab 23:441-453

Sidossis LS, Porter C, Saraf MK, Børsheim E, Radhakrishnan RS, Chao T, Ali A, Chondronikola M, Mlcak R, Finnerty CC, Hawkins HK, Toliver-Kinsky T, Herndon DN (2015) Browning of subcutaneous white adipose tissue in humans after severe adrenergic stress. Cell Metab 22:219-227

Singh AK, Aryal B, Chaube B, Rotllan N, Varela L, Horvath TL, Suárez Y, Fernández-Hernando C (2018) Brown adipose tissue derived ANGPTL4 controls glucose and lipid metabolism and regulates thermogenesis. Mol Metab 11:59-69

Skiba DS, Nosalski R, Mikolajczyk TP, Siedlinski M, Rios FJ, Montezano AC, Jawien J, Olszanecki R, Korbut R, Czesnikiewicz-Guzik M, Touyz RM, Guzik TJ (2017) Antiatherosclerotic effect of the angiotensin 1-7 mimetic AVE0991 is mediated by inhibition of perivascular and plaque inflammation in early atherosclerosis. Br J Pharmacol 174:4055-4069

Stanford KI, Lynes MD, Takahashi H, Baer LA, Arts PJ, May FJ, Lehnig AC, Middelbeek RJW, Richard JJ, So K, Chen EY, Gao F, Narain NR, Distefano G, Shettigar VK, Hirshman MF, Ziolo MT, Kiebish MA, Tseng YH, Coen PM, Goodyear LJ (2018) 12,13-diHOME: an exerciseinduced lipokine that increases skeletal muscle fatty acid uptake. Cell Metab 27:1111-1120

Stefan N, Kantartzis K, Celebi N, Staiger H, Machann J, Schick F, Cegan A, Elcnerova M, Schleicher E, Fritsche A, Häring HU (2010) Circulating palmitoleate strongly and independently predicts insulin sensitivity in humans. Diabetes Care 33:405-407

Stitziel NO, Stirrups KE, Masca NG, Erdmann J, Ferrario PG, König IR, Weeke PE, Webb TR, Auer PL, Schick UM, Lu Y, Zhang H, Dube MP, Goel A, Farrall M, Peloso GM, Won HH, Do R, van Iperen E, Kanoni S, Kruppa J, Mahajan A, Scott RA, Willenberg C, Braund PS, van Capelleveen JC, Doney AS, Donnelly LA, Asselta R, Merlini PA, Duga S, Marziliano N, Denny JC, Shaffer CM, El-Mokhtari NE, Franke A, Gottesman O, Heilmann S, Hengstenberg C, Hoffman P, Holmen OL, Hveem K, Jansson JH, Jöckel KH, Kessler T, Kriebel J, Laugwitz KL, Marouli E, Martinelli N, McCarthy MI, Van Zuydam NR, Meisinger C, Esko T, Mihailov E, Escher SA, Alver M, Moebus S, Morris AD, Müller-Nurasyid M, Nikpay M, Olivieri O, Lemieux Perreault LP, AlQarawi A, Robertson NR, Akinsanya KO, Reilly DF, Vogt TF, Yin W, Asselbergs FW, Kooperberg C, Jackson RD, Stahl E, Strauch K, Varga TV, 
Waldenberger M, Zeng L, Kraja AT, Liu C, Ehret GB, Newton-Cheh C, Chasman DI, Chowdhury R, Ferrario M, Ford I, Jukema JW, Kee F, Kuulasmaa K, Nordestgaard BG, Perola M, Saleheen D, Sattar N, Surendran P, Tregouet D, Young R, Howson JM, Butterworth AS, Danesh J, Ardissino D, Bottinger EP, Erbel R, Franks PW, Girelli D, Hall AS, Hovingh GK, Kastrati A, Lieb W, Meitinger T, Kraus WE, Shah SH, McPherson R, Orho-Melander M, Melander O, Metspalu A, Palmer CN, Peters A, Rader D, Reilly MP, Loos RJ, Reiner AP, Roden DM, Tardif JC, Thompson JR, Wareham NJ, Watkins H, Willer CJ, Kathiresan S, Deloukas P, Samani NJ, Schunkert H (2016) Coding variation in ANGPTL4, LPL, and SVEP1 and the risk of coronary disease. N Engl J Med 374:1134-1144

Subramanian V, Golledge J, Ijaz T, Bruemmer D, Daugherty A (2010) Pioglitazone-induced reductions in atherosclerosis occur via smooth muscle cell-specific interaction with PPAR \{gamma\}. Circ Res 107:953-958

Sui W, Li H, Yang Y, Jing X, Xue F, Cheng J, Dong M, Zhang M, Pan H, Chen Y, Zhang Y, Zhou Q, Shi W, Wang X, Zhang H, Zhang C, Zhang Y, Cao Y (2019) Bladder drug mirabegron exacerbates atherosclerosis through activation of brown fat-mediated lipolysis. Proc Natl Acad Sci U S A 116:10937-10942

Superko HR, Zhao XQ, Hodis HN, Guyton JR (2017) Niacin and heart disease prevention: engraving its tombstone is a mistake. J Clin Lipidol 11:1309-1317

Talukdar S, Zhou Y, Li D, Rossulek M, Dong J, Somayaji V, Weng Y, Clark R, Lanba A, Owen BM, Brenner MB, Trimmer JK, Gropp KE, Chabot JR, Erion DM, Rolph TP, Goodwin B, Calle RA (2016) A long-acting FGF21 molecule, PF-05231023, decreases body weight and improves lipid profile in non-human Primates and type 2 diabetic subjects. Cell Metab 23:427-440

Taskinen MR, Packard CJ, Borén J (2019) Emerging evidence that apoC-III inhibitors provide novel options to reduce the residual CVD. Curr Atheroscler Rep 21:27

Thorp E, Kuriakose G, Shah YM, Gonzalez FJ, Tabas I (2007) Pioglitazone increases macrophage apoptosis and plaque necrosis in advanced atherosclerotic lesions of nondiabetic low-density lipoprotein receptor-null mice. Circulation 116:2182-2190

Tian Z, Miyata K, Tazume H, Sakaguchi H, Kadomatsu T, Horio E, Takahashi O, Komohara Y, Araki K, Hirata Y, Tabata M, Takanashi S, Takeya M, Hao H, Shimabukuro M, Sata M, Kawasuji M, Oike Y (2013) Perivascular adipose tissue-secreted angiopoietin-like protein 2 (Angpt12) accelerates neointimal hyperplasia after endovascular injury. J Mol Cell Cardiol $57: 1-12$

Tsutsumi K, Inoue Y, Shima A, Iwasaki K, Kawamura M, Murase T (1993) The novel compound NO-1886 increases lipoprotein lipase activity with resulting elevation of high density lipoprotein cholesterol, and long-term administration inhibits atherogenesis in the coronary arteries of rats with experimental atherosclerosis. J Clin Invest 92:411-417

van Marken Lichtenbelt WD, Vanhommerig JW, Smulders NM, Drossaerts JM, Kemerink GJ, Bouvy ND, Schrauwen P, Teule GJ (2009) Cold-activated brown adipose tissue in healthy men. N Engl J Med 360:1500-1508

van Wanrooij EJ, de Jager SC, van Es T, de Vos P, Birch HL, Owen DA, Watson RJ, Biessen EA, Chapman GA, van Berkel TJ, Kuiper J (2008) CXCR3 antagonist NBI-74330 attenuates atherosclerotic plaque formation in LDL receptor-deficient mice. Arterioscler Thromb Vasc Biol 28:251-257

Veillard NR, Kwak B, Pelli G, Mulhaupt F, James RW, Proudfoot AE, Mach F (2004) Antagonism of RANTES receptors reduces atherosclerotic plaque formation in mice. Circ Res 94:253-261

Veillard NR, Steffens S, Pelli G, Lu B, Kwak BR, Gerard C, Charo IF, Mach F (2005) Differential influence of chemokine receptors CCR2 and CXCR3 in development of atherosclerosis in vivo. Circulation 112:870-878

Villarroya F, Cereijo R, Villarroya J, Giralt M (2017) Brown adipose tissue as a secretory organ. Nat Rev Endocrinol 13:26-35

Wang GX, Zhao XY, Meng ZX, Kern M, Dietrich A, Chen Z, Cozacov Z, Zhou D, Okunade AL, Su X, Li S, Blüher M, Lin JD (2014) The brown fat-enriched secreted factor Nrg4 preserves metabolic homeostasis through attenuation of hepatic lipogenesis. Nat Med 20:1436-1443 
Weng C, Shen Z, Li X, Jiang W, Peng L, Yuan H, Yang K, Wang J (2017) Effects of chemerin/ CMKLR1 in obesity-induced hypertension and potential mechanism. Am J Transl Res 9:3096-3104

Worthmann A, John C, Rühlemann MC, Baguhl M, Heinsen FA, Schaltenberg N, Heine M, Schlein C, Evangelakos I, Mineo C, Fischer M, Dandri M, Kremoser C, Scheja L, Franke A, Shaul PW, Heeren J (2017) Cold-induced conversion of cholesterol to bile acids in mice shapes the gut microbiome and promotes adaptive thermogenesis. Nat Med 23:839-849

Xiong W, Zhao X, Garcia-Barrio MT, Zhang J, Lin J, Chen YE, Jiang Z, Chang L (2017) MitoNEET in perivascular adipose tissue blunts atherosclerosis under mild cold condition in mice. Front Physiol 8:1032

Xue Y, Xu X, Zhang XQ, Farokhzad OC, Langer R (2016) Preventing diet-induced obesity in mice by adipose tissue transformation and angiogenesis using targeted nanoparticles. Proc Natl Acad Sci U S A 113:5552-5557

Yang ZH, Pryor M, Noguchi A, Sampson M, Johnson B, Pryor M, Donkor K, Amar M, Remaley AT (2019) Dietary palmitoleic acid attenuates atherosclerosis progression and hyperlipidemia in low-density lipoprotein receptor-deficient mice. Mol Nutr Food Res 63:e1900120

Yau H, Rivera K, Lomonaco R, Cusi K (2013) The future of thiazolidinedione therapy in the management of type 2 diabetes mellitus. Curr Diab Rep 13:329-341

Yore MM, Syed I, Moraes-Vieira PM, Zhang T, Herman MA, Homan EA, Patel RT, Lee J, Chen S, Peroni OD, Dhaneshwar AS, Hammarstedt A, Smith U, McGraw TE, Saghatelian A, Kahn BB (2014) Discovery of a class of endogenous mammalian lipids with anti-diabetic and antiinflammatory effects. Cell 159:318-332

Young SG, Zechner R (2013) Biochemistry and pathophysiology of intravascular and intracellular lipolysis. Genes Dev 27:459-584

Zeman M, Vecka M, Perlík F, Staňková B, Hromádka R, Tvrzická E, Širc J, Hrib J, Žák A (2016) Pleiotropic effects of niacin: current possibilities for its clinical use. Acta Pharma 66:449-469

Zhang F, Hao G, Shao M, Nham K, An Y, Wang Q, Zhu Y, Kusminski CM, Hassan G, Gupta RK, Zhai Q, Sun X, Scherer PE, Oz OK (2018) An adipose tissue atlas: an image-guided identification of human-like BAT and beige depots in rodents. Cell Metab 27:252-262

Open Access This chapter is licensed under the terms of the Creative Commons Attribution 4.0 International License (http://creativecommons.org/licenses/by/4.0/), which permits use, sharing, adaptation, distribution and reproduction in any medium or format, as long as you give appropriate credit to the original author(s) and the source, provide a link to the Creative Commons licence and indicate if changes were made.

The images or other third party material in this chapter are included in the chapter's Creative Commons licence, unless indicated otherwise in a credit line to the material. If material is not included in the chapter's Creative Commons licence and your intended use is not permitted by statutory regulation or exceeds the permitted use, you will need to obtain permission directly from the copyright holder.

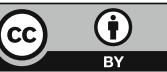

